\title{
The Nexus Between Finance And Entrepreneurship For The Nigerian Economic Growth
}

\author{
Tomola M. Obamuyi (Ph.D) \\ Department of Economics, School of Management Technology, \\ Federal University of Technology, Akure, Nigeria.
}

\author{
Grace 0. Iriobe \\ Department of Financial Studies, College of Management and Social sciences, \\ Redeemer's University, Ede, Nigeria.
}

\begin{abstract}
This study examined the nexus between finance and entrepreneurship for the Nigerian economic growth, using endogenous growth framework. Multivariate time series was employed to analyze the secondary data. Tests such as the unit root, co-integration and the vector error correction model were carried out for the empirical analysis. The normalised long-run co-integrating equation supported by the short-run dynamics showed that finance, entrepreneurship, interest rate, and industrial productivity are significant to economic growth in Nigeria. The paper concluded that the government should formulate effective macroeconomic policy targeted to entrepreneurship financing and growth. The paper further called for the overhauling of agencies and institutions set up for entrepreneurship to maximize the impact of entrepreneurial finance on the Nigerian economic growth.
\end{abstract}

Keywords: Economic Growth, Finance, Entrepreneurship, Interest Rate, Inflation Rate, Industrial Production Index

Word Count: 118

\section{INTRODUCTION}

Access to finance is one of the challenges facing entrepreneurs in starting businesses. Attention of governments and stakeholders the world over has been drawn to this because of the important role entrepreneurship play in economic development (Organisation for Economic Co-operation and Development, OECD 2006). Entrepreneurial activities are usually at the heart of most economic programs and policies of various countries however, the strength of the financial intermediaries to a large extent determines economic growth (Levine et al. 2000).

Since 1960, there have been different plans by various governments in Nigeria to create a workable plan for economic development. Most of these developmental policies have entrepreneurs and entrepreneurial activities at the centre of its objective (Ayanda and Adeyemi 2011). The impact and contributions of entrepreneurship in most developed countries has been the reason most emerging economies are focusing on entrepreneurship to grow their economy. In developed nations, governments are urged to promote the availability of risk capital financing for entrepreneurs (OECD 2004). Unfortunately, financing system has consistently dragged and constrained the development of entrepreneurship and economic growth because of weak legal system (Levine, 1999).

Although entrepreneurship has no singular definition, its impact in terms of job creation (Folster, 2000); productivity (Baumol, 1990), and economic transformation (Audretsch et al., 
2002) have been well documented in literature. However, one factor that scholars are yet to agree on is the role finance institutions play in the relationship between entrepreneurship and economic growth (King and Levine 1993). In this paper, we explored the role financial intermediaries' play in the relationship between entrepreneurship and economic growth. Previous studies have shown that financial intermediaries are developed through reform in legal and accounting systems that strengthen creditor rights, contract enforcement, and this in turn accelerate economic growth.

With the various legal and accounting reforms going on in Nigeria since May 1999, this study intends to investigate what role intermediation has played in the Entrepreneurship and Economic growth Nexus

\section{LITERATURE REVIEW}

Entrepreneurs are the foundation of economic growth in developed economies. However, impact of access to finance has always been a challenge to the development of entrepreneurship especially in developing nations. The Global Entrepreneurship Monitor, GEM (2017) categorized countries where entrepreneurship play a dominant role in their economy into innovation-driven economies (Belgium, Denmark, Germany, Greece, Spain, France, Italy, Netherlands, Sweden, United Kingdom, Norway and Switzerland; and efficiency-driven economies: (Latvia, Hungary, Romania, Croatia and Turkey). For these countries, entrepreneurship has contributed more to their economic growth than government activities have done when compared to developing economies (Naude, 2011; Anokhin and Schulze, 2009), and the policies and programs aimed at entrepreneurship development are reviewed regularly (Olutunla and Obamuyi, 2008).

In developing economies, the government determine the direction of the economic activities and Nigeria is no exception. Since 1960, the federal government of Nigeria have been developing programmes to enhance entrepreneurship and boost economic growth. For instance, the federal government of Nigeria increased its effort towards entrepreneurship development through programmes such as Structural Adjustment Program (SAP), National Directorate of Employment (NDE), National Open Apprenticeship Scheme (NOAS) and, the Small and Medium Enterprise Development Association of Nigeria (SMEDAN). The government went a step further to make Entrepreneurship Studies a mandatory course in schools (Thaddeus, 2012). These efforts notwithstanding, entrepreneurial activities in Nigeria still contribute less than 50\% to the GDP (NBS 2016).

No doubt, entrepreneurship is a major factor in job creation and boosting of the nation's GDP (SMADAN/NBS 2010). However, accessing finance is a major constraint to the activities of aspiring entrepreneurs (Tambunan 2007). Nigeria has about the lowest fund committed to entrepreneurial activities (CBN 2009), and this accounts for entrepreneurs inability to embrace the opportunity technology and globalization created. In Nigeria, finance is still a constraint to entrepreneurship development despite Central bank of Nigeria's directives to banks to make funds available to entrepreneurs. Even developed nations are making the supply of venture capitals to entrepreneurs through public policy (Gilson 2003; Cumming and MacIntosh 2007).

Although entrepreneurship is considered to have a positive relationship with economic growth (Audretsch et al 2006), the Global Entrepreneurship Monitor, GEM (2017) however identified phases of entrepreneurial activities, and each of these phases are affected by diverse factors within an economy. 
According to GEM (2017), "The phases start out with potential entrepreneurs: those that see opportunities in their area and believe they have the capabilities to start businesses; the cycle continues: intent to start a business is followed by nascent activity, defined as entrepreneurs who are in the first three months of running a new business. New business owners are former nascent entrepreneurs; they have been in business more than three months, but less than three and a half years. Together, nascent and new entrepreneurs compose total early-stage entrepreneurial activity (TEA). Additional phases include established business ownership as well as business discontinuation, which can supply society with experienced entrepreneurs who may go on to start another business or to use their expertise and resources to benefit entrepreneurs in some way (through financing, advising, or other forms of support)." Each of the phases or stages of entrepreneurship vary when different components of economic growth, and the stages of economic development in various countries are considered (Reynolds et al.2003; Van Stel, Carree, and Thurik 2004; Schultz 1990).

Various studies (Adusei, (2016); Giordani, (2015); Audretsch, Bonte and Keilbach (2008) and others) have acknowledged the relationship between entrepreneurship and economic growth with different outcomes, Boettke and Coyne (2003) argue that entrepreneurship does not have a direct relationship with development, and that the type of entrepreneurship adopted lead to economic growth. Valliere and Peterson (2009) further studied the influence of different types of entrepreneurship on economic growth between developed and emerging countries. According to them, the conflict in outcomes of earlier results is because of differences in entrepreneurial types and motivation as well as between push and pull forces that were not controlled.

In spite of the evidences that abound regarding the relationship between entrepreneurship and economic growth, only data from developed nations are available to answer some of the questions on the entrepreneurship and economic growth nexus (Anokhin and Schulze, 2009). For instance, the impact of financial intermediation in the relationship has not be answered given the peculiar financial system operated in developing nations. Experts however, have identified factors such as innovation efforts (Audretsch et al., 2008), university-industry relations (Mueller, 2006), financial literacy (ACCA, 2014) as important in the entrepreneurship-economic growth nexus. However, Bosma et al 2005, Wang 2006 argued that the growth of the GDP, investments, cost, interest rate and inflation seems to play a major role in influencing entrepreneurship.

The pattern of access to finance in Eastern Europe influences economic growth. In Nigeria, although previous studies (Afolabi, 2015; Ogbo and Nwachukwu, 2012; Popoola, 2014; Ahiauzu, 2010; Tende, 2014) have examined the impact of finance on entrepreneurship, the influence of finance and entrepreneurship in economic growth has not been adequately studied. Neren (2006) however was of the opinion that in most developing economies, financing activities does not contribute much to entrepreneurship and the influence on economic growth is yet to be ascertained. It is against this background that this study examined the nexus between finance and entrepreneurship for the economic growth of Nigeria.

\section{METHODOLOGY}

The paper employed time series quarterly data covering 20 years (1997-2016) to estimate the long-run and causal relationships between finance and entrepreneurship for Nigeria's economic growth. The data was sourced from the Central Bank of Nigeria e- database, World Bank reports and National Bureau of Statistics. The Econometric View (E-view) Version 7 statistical package was used for data analysis. Also, stationarity test was used to establish the 
order of integration of the series which was done by applying the Augmented Dickey-Fuller (1979) test; a Co-integration test to check the long-run relationship between the study variables using a multivariate co-integration model; and the Error Correction Model (ECM) to determine the nature of the relationships between variables

This paper adopted endogenous macroeconomic variables such as Entrepreneurship (ENT), Finance (FIN), the Industrial Production Index (IPI), Interest Rate (INT), Inflation Rate (INF), and Real Gross Domestic Products (RGDP), which were properly operationalised in this study. These variables were sufficiently adopted in the works of Bosma et al (2005); Audretsch et al (2006); Wang, 2006; Tambunan, (2007); Anokhin and Schulze, (2009); OECD, (2009); Naude, 2011; and Somoye, (2013). The linear model is specified as:

$$
\mathrm{RGDP}_{\mathrm{t}}=\beta_{0}+\beta_{1} \mathrm{FIN}_{\mathrm{t}}+\beta_{2} \mathrm{ENT}_{\mathrm{t}}+\beta_{3} \mathrm{INT}_{\mathrm{t}}+\beta_{4} \mathrm{INF}_{\mathrm{t}}+\beta_{5} \mathrm{IPI}_{\mathrm{t}}+\mu_{\mathrm{t}} \ldots .
$$

Where,

RGDP= Real GDP

FIN= Financial intermediation at macro level as proxied by $\mathrm{M}_{2} / \mathrm{GDP}$

ENT= Entrepreneurship

INT- Interest rates as proxied by prime lending rate

$\mathrm{INF}=$ Inflation rates as proxied by CPI

IPI= Industrial production index

$\beta_{0}=$ Constant term

$\beta_{1}, . ., \beta_{5}=$ Coefficients

$\mu=$ Error terms assumed to be normally distributed with constant variances respectively.

The real GDP (RGDP) is the dependent variable on which the regression is normalized. It is expected that $B_{1}>0, B_{2}>0, B_{5}>0$ of Finance (FIN), Entrepreneurship (ENT), and Industrial Production Index (IPI) respectively are expected to exert positive significant relationship to RGDP, while coefficient $\mathrm{B}_{3}<0$ of Interest Rates (INT), and $\mathrm{B}_{4}<0$ of Inflation Rates (INF) are expected to be negatively significant to RGDP in the long-run. The error term in the equation above $\mu$ is expected to be well- behaved while $t$ is the time variant.

The economic implication of the a priori expectation is that the level of finance (Financial intermediation deepening) will significantly improve the growth of the economy in both long run and short run (CBN, 2009; and Somoye, 2013). Consequently, improvement in entrepreneurship activities which may have resulted from the level of financial deepening ought to have influence on economic growth. Also, increase in productivity and unemployment rate is expected to lead to economic growth because increase in entrepreneurship activities will increase productivity, and a rise in unemployment rate will spur more entrepreneurship activities which will in turn influence economic growth. Unemployment rate may also exert pressure on the Nigerian government to formulate and implement effective policies on entrepreneurship development (OECD, 2009). However, low level of interest rates and inflation rates will improve the investment and financing capacity of entrepreneurs and allow them to borrow at low transaction costs while improving productivity and influence the growth and development of the economy. Thus, the study variables were measured and justifies as follows: 
Table 1: Measurement and justification of variables

\begin{tabular}{|c|c|c|c|}
\hline Symbols & Variables & Measurement of Variables & Previous Studies \\
\hline & Dependent Variable & & \\
\hline \multirow[t]{3}{*}{ RGDP } & $\begin{array}{l}\text { Real Gross Domestic } \\
\text { Product }\end{array}$ & $\begin{array}{l}\text { LogGDP measured as a ratio of } \\
\text { GDP at current market price to } \\
\text { implicit price deplator (IPD) }\end{array}$ & Somoye (2013) \\
\hline & Independent Variables & & \\
\hline & Finance & $\begin{array}{l}\text { Ratio of total money outside } \\
\text { the banking system and } \\
\text { money supply (M2) to GDP } \\
\left(\mathrm{M}_{2} / \mathrm{GDP}\right)\end{array}$ & $\begin{array}{l}\text { CBN, (2009); } \\
\text { Giordani, (2013) }\end{array}$ \\
\hline ENT & Entrepreneurship & $\begin{array}{l}\text { Ratio of total loans approved } \\
\text { for entrepreneurship from } \\
\text { formal sources to total credits } \\
\text { to the private sector }\end{array}$ & $\begin{array}{l}\text { Audretsch et al (2006) } \\
\text { and OECD, (2009) }\end{array}$ \\
\hline INT & Interest Rate & $\begin{array}{l}\text { Market interest rates as } \\
\text { proxied by prime lending } \\
\text { rates }\end{array}$ & $\begin{array}{l}\text { Tambunan 2007, } \\
\text { Bosma et al 2005, and } \\
\text { Wang } 2006\end{array}$ \\
\hline INF & Inflation Rate & $\begin{array}{l}\text { Official inflation rate as } \\
\text { proxied by consumer price } \\
\text { index (CPI) }\end{array}$ & $\begin{array}{l}\text { Tambunan 2007, } \\
\text { Bosma et al 2005, and } \\
\text { Wang } 2006\end{array}$ \\
\hline IPI & $\begin{array}{l}\text { Industrial production } \\
\text { Index }\end{array}$ & $\begin{array}{l}\text { Measurement of IPI by the } \\
\text { CBN }\end{array}$ & CBN (2009) \\
\hline
\end{tabular}

Source: Researchers' compilation, 2018

\section{Unit Root Tests}

\section{ANALYSIS AND RESULTS}

The unit root test result in Table 2 above reveals that all the variables are stationary at first difference using Augmented Dick-Fuller Test. Hence, at 5\% level of significance, all the variables are suitable for co-integration analysis. It can then be concluded that the data used in the regression analysis are stable.

Table 2: Augmented Dickey-Fuller Result

\begin{tabular}{|l|l|l|l|l|}
\hline Variable & T-statistic & Order of Integration & Stationary & Order of Integration \\
\hline RGDP & 2.8843 & $1(1)$ & Stationary & First Difference \\
\hline FIN & 0.5898 & $1(1)$ & Stationary & First Difference \\
\hline ENT & 2.3897 & $1(1)$ & Stationary & First Difference \\
\hline INT & 0.4897 & $1(1)$ & Stationary & First Difference \\
\hline INF & 2.6407 & $1(1)$ & Stationary & First Difference \\
\hline IPI & 7.9939 & $1(1)$ & Stationary & First Difference \\
\hline
\end{tabular}

Source: Researchers' E-views (7) output, 2018

\section{Co-integration Tests}

The result from Table 3 above indicates that the null hypothesis of no co-integration is accepted by both the Trace and the Maximum-Eigen Value tests. Both tests indicate that no co- 
integrating equation exists among linear combinations of finance, entrepreneurship and economic growth in Nigeria and it is hypothesised at 5\% level of significance. The result shows that the hypothesised determinants are generally I(1) series and that there are some stable long run equilibrium relationship among the series which could be given some error correction representations (Engle and Granger, 1987 in Somoye, 2013) which rules out the possibility of a spurious relationship among the variables. Therefore, we employ the Vector Error Correction Model (VECM) to estimate the long-run and short-run equilibrium relationship among the series.

Table 3: Result of Co-integration Tests

\begin{tabular}{|l|c|c|c|c|}
\hline $\begin{array}{l}\text { Hypothesised No } \\
\text { of co-integrating } \\
\text { Equations (CEs) }\end{array}$ & $\begin{array}{l}|c| \\
\text { Trace Statistics } \\
(\mathrm{P}<0.05)\end{array}$ & Critical Value & $\begin{array}{l}\text { Max-Eigen } \\
\text { Statistic }\end{array}$ & $\begin{array}{l}\text { Critical Value } \\
(\mathrm{P}<0.05)\end{array}$ \\
\hline None & 97.6534 & 95.7537 & 32.0569 & 40.0776 \\
\hline At most 1 & 65.5965 & 69.8189 & 26.5182 & 33.8769 \\
\hline At most 2 & 39.0783 & 47.8561 & 15.4879 & 27.5843 \\
\hline At most 3 & 23.5904 & 29.7971 & 13.5318 & 21.1316 \\
\hline At most 4 & 10.0586 & 15.4947 & 8.8255 & 14.2646 \\
\hline At most 5 & 1.2332 & 3.8415 & 1.2332 & 3.8415 \\
\hline
\end{tabular}

Source: Researchers' E-views (7) output, 2018

\section{Vector Error Correction Model (VECM) Result}

The estimated long-run equilibrium obtained from the co-integration of the model normalized on Real GDP is presented below:

Table 4: Summary of Normalized co-integration Test

\begin{tabular}{|l|l|l|}
\hline Variables & Normalized coefficients & Significance $(\mathrm{p}<0.05)$ \\
\hline C & 0.4142 & - \\
\hline FIN & 0.3428 & 0.0178 \\
\hline ENT & 0.2601 & 0.0243 \\
\hline INT & -0.0525 & 0.0393 \\
\hline INF & 0.7228 & 0.2250 \\
\hline IPI & 1.2214 & 0.0399 \\
\hline$R^{2}$ & 0.3270 & \\
\hline F-stat & 0.0001 & \\
\hline
\end{tabular}

Source: Researchers' E-views (7) output, 2018

Table 4 shows that FIN, ENT, and IPI exert positive and significant influence on RGDP in Nigeria. This implies that one percent (1\%) increase in finance, entrepreneurship, and industrial production index will cause the economy to grow at approximately $0.34 \%, 0.26 \%$ and $1.22 \%$ respectively in the long run. However, inflation rates exert a positive but insignificant relationship with economic growth. Also, interest rates exert a negative and insignificant relationship with economic growth. The negative relationship of these variables suggests that when there is a $1 \%$ rise in interest rate, the economic declines at $0.05 \%$.

This result confirms some of the a priori expectations that finance, entrepreneurship, and industrial production index will positively influence the rate of growth in the economy; and that interest rates will exert negative impact on the economy. However, the expectation on the relationship between inflation rate and economic growth did not hold. The positive influence of inflation on economic growth, though not expected, but would result in economic growth. 
Nonetheless, government must ensure the implementation of policies that would reduce inflation rate so as to encourage increase in the level of business investment (especially for entrepreneurship) and to encourage the efficiency with which productive factors of the economy are put to use.

The coefficient of determination $\left(\mathrm{R}^{2}\right)$ of approximately 33\% implies that the variation in economic growth is explained by the variations in the other endogenous variables in the model. However, there is no problem of autocorrelation in the analysis as this has been incorporated in the co-integration mechanism during the stages of unit root and co-integration tests.

The broad implication of the result in Table 4 is that government policy measures aimed at stimulating economic growth through finance and entrepreneurship must be accompanied by measures to reduce interest rate on credit and inflation rate to promote industrial production activities. From this analysis, we therefore accept the alternative hypothesis that finance and entrepreneurship activities have significant influence on the economic growth of Nigeria.

Table 5: Summary of Short Run Equilibrium Estimates

\begin{tabular}{|l|l|l|l|l|l|}
\hline \multicolumn{7}{|c|}{ Short Run Estimates } & \multicolumn{2}{l}{} \\
\cline { 1 - 3 } Variable & Coefficient & t-stat & Prob & \multicolumn{2}{l}{ Statistical Properties of Results } \\
\hline LOG(RGDP) t- & 0.6113 & 7.162 & 0.000 & & \\
\hline LOG(FIN) & 0.3052 & 0.0125 & 0.015 & R-squared & 0.47 \\
\hline ENT & 0.5170 & 0.016 & 0.000 & Adj R-squared & 0.41 \\
\hline INT & -0.1042 & 0.0134 & 0.408 & F-statistic & 1.8039 \\
\hline INF & 0.1261 & 0.3025 & 0.041 & Prob(F-statistic) & 0.004 \\
\hline IPI & 0.02021 & 0.37481 & 0.0286 & Durbin-Watson Stat & 2.000 \\
CointEq(-1)* & -0.0499 & 5.2715 & 0.0000 & & \\
\hline
\end{tabular}

Source: Researchers' E-views (7) output, 2018

The VECM results in this study indicate a short run relationship between the endogenous variables. The error correction coefficient (ECM) of economic growth is -0.0499 and significant at $\mathrm{f}=-1.8039$. This shows that the adjustment of the short run equilibrium to the shocks to its equilibrium relationship with its hypothesised determinants is significant. Hence, the shortrun equilibrium dynamics supports that of co-integration.

\section{DISCUSSION OF FINDINGS}

From the result above, the study model exhibited both long-run and short-run dynamics and uni-directional causal relationship between the endogenous variables. The result is consistent with the work of Somoye (2013) that a weak causal relationship exists between finance and entrepreneurship while finance and entrepreneurship exhibit a positive significant influence on the economic growth of Nigeria. Also, finance, entrepreneurship, inflation rate and industrial production index will positively influence the rate of growth in the economy; and that interest rates will exert negative impact on the economy. This submission validates literature as observed in GEM (2017) that entrepreneurship play a dominant role in every economy. However, entrepreneurship and finance does not have a direct relationship with economic development, but rather the type of entrepreneurial financing adopted may lead to economic growth. This submission is in line with the argument of Boettke and Coyne (2003).

Valliere and Peterson (2009) opine that conflict in outcomes of these results could be because of differences in entrepreneurial types and motivation as well as between push and pull forces that were not controlled. OECD (2009) in Somoye (2013) asserted that global financial crises 
serves as a major threat to accessing finance for entrepreneurship activities in developing economies like Nigeria. The Central Bank of Nigeria has overtime implemented policies to strengthen the Nigerian financial system but, not much is achieved as interest rate, inflation rate and unemployment rate are still on the rise (Afolabi, 2015) while access to finance for entrepreneurship and industrial production index are falling.

\section{CONCLUSION AND RECOMMENDATIONS}

This study has shown that finance and entrepreneurship activities have significant influence on the economic growth of Nigeria. Therefore, we conclude that, there is a significant and crucial relationship between finance and entrepreneurship and this is pertinent for the growth and development of the Nigerian economy. Here, finance is a major requirement for the enhancement of entrepreneurship growth which will in turn foster economic growth. Also, the Nigerian business environment coupled with government policies and programmes is very unstable and turbulent to encourage entrepreneurial finance, and that interest rate is still a bane to economic activities to economic growth and development in Nigeria.

Drawing from the conclusion above, the study recommends that the Nigerian government should formulate economic policies that will counteract the effects of financial crisis on entrepreneurial financing. However, these economic policies should be targeted specifically to ease access to finance for entrepreneurship purpose thereby contributing to the growth of the economy. Also, the agencies and institutions set up for entrepreneurship financing purpose should be properly regulated with a view to encourage entrepreneurship development in the country and by this, the impact of entrepreneurial finance in terms of improving industrial production index will be felt on the growth of the Nigerian economy at large. Lastly, we recommend that government policy measures aimed at improving economic growth should have both short-run and long-run implications on the changes in the level of Finance, Entrepreneurship, Interest rate, Inflation rate, and Industrial production index to ensure consistency in the growth of the Nigerian economy.

\section{Reference}

ACCA. (2014). Financial education for entrepreneurs : what next? The Association of Chartered Certified Accountants, 1-20.

Adusei, M. (2016). Does Entrepreneurship Promote Economic Growth in Africa? African Development Review, 28(2), 201-214.

Anokhin, S. and W. S. Schulze (2009). 'Entrepreneurship, Innovation, and Corruption', Journal of Business Venturing, 24(1) 465-76.

Audretsch, D. B., M. C. Keilbach, and E. E. Lehmann (2006). Entrepreneurship and Economic Growth, Oxford University Press, New York.

Audretsch, D. B., W. Bonte and M. Keilbach (2008). 'Entrepreneurship Capital and its Impact on Knowledge Diffusion and Economic Performance', Journal of Business Venturing, 23(1), 687-98.

Boettke, Peter J., and Christopher J. Coyne. (2003). “Entrepreneurship and Development: Cause or Consequence?” Advances in Austrian Economics, 6(1), 67-87.

Bosma, N., de Wit, G. and Carree, M., (2005), "Modelling Entrepreneurship: Unifying the Equilibrium and the Entry /Exit Approach", Small Business Economics, 25(2), 35-48.

Carree, M. A., \& Thurik, A. R. (2003). The Impact of Entrepreneurship on Economic Growth. International Handbook of Entrepreneurship Research, 437-71.

Central Bank of Nigeria (2009). Statistical Bulletin. Central Bank of Nigeria Publication, 20(1), 1-513.

Christian Friis, Thomas Paulsson, C. K. (2002). Entrepreneurship and Economic Growth Entrepreneurship and Economic Growth. Jönköping International Business School. Retrieved on 23/10/2017

http://doi.org/10.1093/acprof:oso/9780195183511.001.0001. 
Cumming, Douglas J and Jerey G MacIntosh. (2007). "Mutual funds that invest in private equity? An analysis of labour-sponsored investment funds." Cambridge Journal of Economics, 31(1), 445-487.

Gilson, Ronald J. (2003). “Engineering a Venture Vapital Market: Lessons from the American Experience." Stanford Law Review, 55 (1), 1067-1104.

Giordani, P. E. (2015). Entrepreneurial Finance and Economic Growth. Journal of Economics, 115(2013), 153-174.

Global Entrepreneurship Monitor, GEM (2017). 2016/2017 GEM Global Report, www.rothko.co.za, 1-180.

Gries, T., \& Naudé, W. (2009). Entrepreneurship and regional economic growth: towards a general theory of startups. Innovation: The European Journal of Social Science Research, 22(3), 309-328.

Levine, R., King, R. G., \& Levine, R. (2016). Finance , entrepreneurship and growth : Theory and evidence, New Edition, 513-542.

Kelley, D. J., Singer, S., \& Herrington, M. (2012). Global Entrepreneurship Monitor: Global Report 2011. Babson College, Universidad Del Desarrollo, Universiti Tun Abdul Razak, 38. Retrieved on 21/08/17 from

http://scholar.google.com/scholar?hl=en\&btnG=Search\&q=intitle:Global+Entrepreneurship+Monitor+2011+Glob al+Report\#8

Mueller, P. (2006), 'Exploring the Knowledge Filter: How Entrepreneurship and University-Industry Relationships Drive Economic Growth', Research Policy, 35 (1), 1499-508.

Naudé, W. W. (2013). Entrepreneurship and Economic Development : Theory, Evidence and Policy. IZA Discussion Paper, (7507), 1-20.

Ogbo, A. and Nwachukwu, A. C. (2012). The Role of Entrepreneurship in Economic Development: The Nigerian Perspective. European Journal of Business and Management, 4(8), 1-10.

OECD (2009). The Impact of the Global Crisis on SME and Entrepreneurship Financing and Policy Responses Centre for Entrepreneurship, SMEs and Local Development, Organisation for Economic Co-operation and Development. Paris: OECD, Paris.

Oyelola, O. T., Ajiboshin, I. O., Raimi, L., Raheem, S., and Igwe, .C. N. (2013). Entrepreneurship for Sustainable Economic Growth in Nigeria. Journal of Sustainable Development Studies, 2(2), 197-215.

Oyeniran, I. W., David, O. O., and Ajayi, O. (2015). Small and Medium Scale Enterprises and Economic Growth in Nigeria: AN Autoregressive Distributed Lag (ARDL) Approach. Finance of Micro, Small \& Medium Scale Enterprise in Nigeria, 341-354.

Popoola, A. T. (2014). Entrepreneurship to the Rescue. Tomeb Foundation for Youth Development and Sustainability and Member of Global Entrepreneurship Monitor (GEM), Nigeria Team, 1-4.

Samila, S., \& Sorenson, O. (2011). Venture Capital, Entrepreneurship, and Economic Growth. Review of Economics and Statistics, 93(1), 338-349.

Schultz, T.P. (1990), Women's changing participation in the labor force: a world perspective, Economic Development and Cultural Change 38, 457-488.

Somoye, R.O.C. (2013). The Impact of Finance on Entrepreneurship Growth in Nigeria: A Co-Integration Framework. ACRN Journal of Entrepreneurship perspective 2(2) 21-25

Valliere, D., \& Peterson, R. (2009). Entrepreneurship and economic growth: Evidence from emerging and developed countries. Entrepreneurship \& Regional Development, 21(5), 459-480.

Thurik, R. (2009). Entrepreneurship, Economic Growth and Policy in Emerging Economies. Development, 1-20. Retrieved on 14/08/17 from http://doi.org/10.1017/CB09780511805950.011\%20

NBS. (2016). Nigerian Gross Domestic Product Report Q2 2016, (February). Retrieved on 12/08/17 from http://www.nigerianstat.gov.ng/nanapages/download/329

Samila, S., \& Sorenson, O. (2011). Venture capital, entrepreneurship, and economic growth. The Review of Economics and Statistics, 93(1), 338-349.

Miniti, M., and M, Levesque, 2006. Entrepreneurial types and economic growth. Paper presented at the international conference on entrepreneurship in emerging regions, December 5-7, in Hyderabad, India.

Reynolds, P. and Storey, D., (1993), Local and Regional characteristics Affecting Small Busin Formation: A CrossNational Comparison, $O E C D$, Paris. 
Tambunan, T. T. H. (2011). Development of small and medium enterprises in a developing country: The Indonesian case. Journal of Enterprising Communities: People and Places in the Global Economy, 5(1), 68-82. http://doi.org/10.1108/17506201111119626

Van Stel, A., M. Carree and R. Thurik (2005), 'The Effect of Entrepreneurship on National Economic Growth', Small Business Economics, 23 (1), 311-21.

Wong, P.K., Y.P. Ho, and E. Autio. 2005. Entrepreneurship, innovation and economic growth: Evidence from GEM data, Small Business Economics 24(1), 335-50 